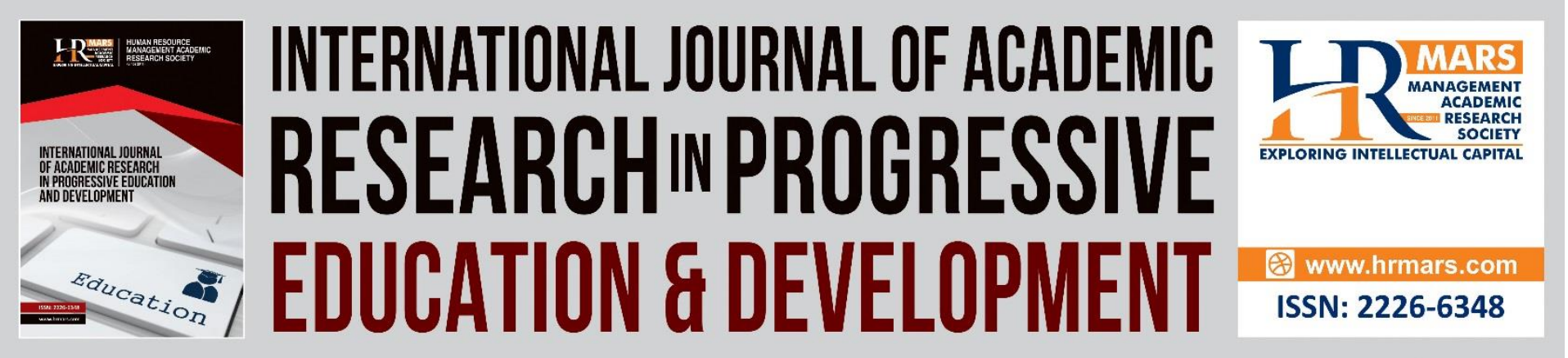

\title{
Causes of Burnout among Secondary School Teachers: A Case of Bungoma North District-Kenya
}

Margret N. Sichambo, Samuel N. Maragia, Agrrey M. Simiyu

To Link this Article: http://dx.doi.org/10.6007/IJARPED/v1-i4/11964

DOI: 10.6007/IJARPED/v1-i4/11964

Received: 18 September 2012, Revised: 21 October 2012, Accepted: 28 October 2012

Published Online: 23 November 2012

In-Text Citation: (Sichambo et al., 2012)

To Cite this Article: Sichambo, M. N., Maragia, S. N., \& Simiyu, A. M. (2012). Causes of Burnout among Secondary School Teachers: A Case of Bungoma North District-Kenya. International Journal of Academic Research in Progressive Education and Development, 1(4), 16-23.

Copyright: (c) 2012 The Author(s)

Published by Human Resource Management Academic Research Society (www.hrmars.com)

This article is published under the Creative Commons Attribution (CC BY 4.0) license. Anyone may reproduce, distribute, translate and create derivative works of this article (for both commercial and non-commercial purposes), subject to full attribution to the original publication and authors. The full terms of this license may be seen

at: http://creativecommons.org/licences/by/4.0/legalcode

Vol. 1(4) 2012, Pg. 16 - 23

http://hrmars.com/index.php/pages/detail/IJARPED

JOURNAL HOMEPAGE

Full Terms \& Conditions of access and use can be found at

http://hrmars.com/index.php/pages/detail/publication-ethics 


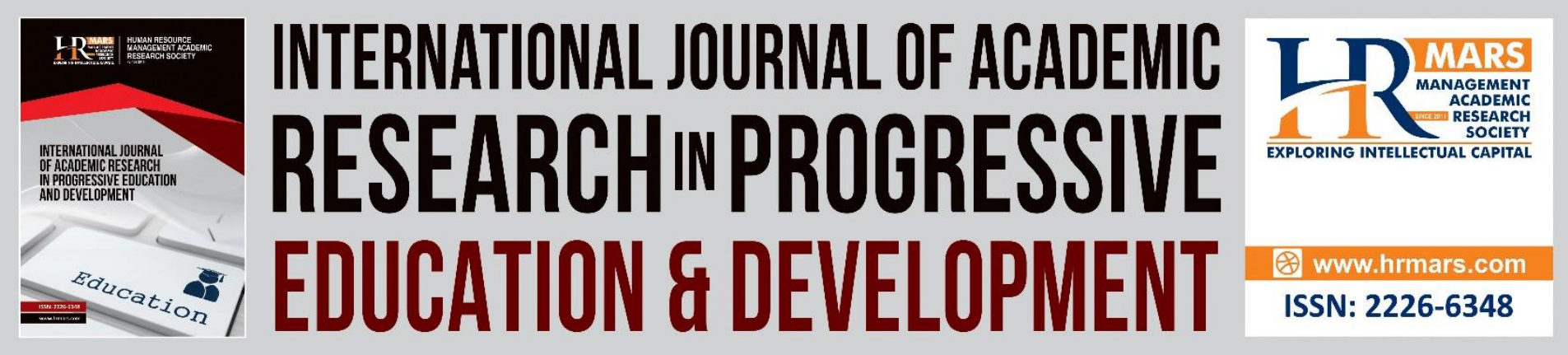

\title{
Causes of Burnout among Secondary School Teachers: A Case of Bungoma North District- Kenya
}

\author{
Ms. Margret N. Sichambo \\ Department of Educational Pyschology, Masinde Muliro University of Science and \\ Technology, P.O. Box 190, Kakamega - Kenya \\ Email: margaretsichambo@yahoo.com \\ Dr. Samuel N. Maragia \\ Department of Educational Psychology, Masinde Muliro University of Science and \\ Technology, P.O. Box 190, Kakamega - Kenya \\ Email: samuelmaragia@yahoo.com \\ Prof. Agrrey M. Simiyu \\ Department of Curriculum and Instruction Technology, Masinde Muliro University of \\ Science and Technology, P.O. Box 190, Kakamega - Kenya \\ Email: simiyumukasa@yahoo.com
}

\begin{abstract}
Teachers are key players in the achievement of educational goals in any country. To achieve this goals, their well-being is important and their issues need to be addressed. Burnout among teachers is one of the biggest issues which need attention. Burnout is a feeling of tiredness; low enthusiasm and going out of work mechanically. It can result from prolonged exposure to stress. The purpose of this study was to investigate the causes of burnout among secondary schools teachers in Bungoma North District of Bungoma County, Kenya. The study population comprised of 37 secondary schools having 544 teachers. Eighteen schools were sampled which included five provincial schools and thirteen district schools. In the provincial schools category, two were boys' schools, two mixed and one girls' school and that is the only Provincial Girls' School in the district. District Schools comprised of three boys' schools, three girls' schools and seven mixed schools. The sample size was 180 teachers and 18 Principals. This sample was obtained by selecting 10 teachers from each sampled school using stratified random sampling and 1 principal from each of the sampled schools using purposive sampling. Data was collected using questionnaires, document analysis, task performance schedule and interview schedule. Analysis was done using descriptive statistics and was presented on tables, pie charts and graphs.

The study revealed that apart from the normal classroom teaching, teachers had a number of remedial lessons to attend to, larger classes to handle, a lot of paper work and some had to
\end{abstract}


stay in their work stations other than their normal school timings in order to complete various tasks. All these factors were contributing in burnout among teachers which were badly impacting their performance. The study recommended that the weekend remedial lessons should be discontinued, regular transfers on request should be in practice and some relaxation time should be given to teachers. The findings of the study gave insight to school administrators, the Ministry of Education and individual teachers on the existence of burnout among teachers.

Keywords: Burnout, Teachers, Stress, Performance

\section{Introduction}

Due to the importance of Education in the Socio-Economic development of an individual, great efforts are always made to ensure that an individual goes through the Education cycle successfully by achieving high academic results (Chance, 1981). The need for good results puts every stake-holder in the Education Sector on alert. Many mechanisms are put in place to ensure high performance and good results. Such mechanisms includes; introducing performance contracts by the government, initiation of Free Primary Education (FPE) and Subsidizing Secondary Education (SSE), increasing in contact hours between the teacher and learner, holiday tuition, remedial teaching during weekends, intensive testing policies etc.

Teachers who are the key players in the achievement of educational goals in the country feel that they are overloaded with work. They are exposed to larger classes of students but have very limited facilities. Most teachers are exposed to prolonged stress which eventually culminates into burnout. As a result of burnout the previously committed teachers become detached from their jobs or continue with the job mechanically because they have no other option otherwise. Teachers experiencing burnout have low commitment and enthusiasm towards their work which can be reflected in their job performance (Kyriancou 2001). Though there is a big concern for good standards of education in Kenya, various researches reveal low morale among teachers (Karugu, 1980). There is an alarming turnover of teachers to better paying careers which can be attributed to burnout.

Desire for progress and improvement in academics; urge to be ranked as top performing school and maintaining top positions, rivalry and competition among secondary schools and subject teachers have lead to the creation of many programmes in schools besides the normal classroom teaching. As the programmes begin, teachers are very enthusiastic but as the time passes they have to face workload, deadlines, remedial teaching, regular continuous assessments and because of all these factors the teacher quickly gets overwhelmed and usually effort and time in most schools is not reflected in the end results hence low productivity.

\section{Statement of The Problem}

Jobs are a central source of stress and burnout as most people spend most of their time at workplace (Looker, 2007). Teachers are exposed to many situations that cause burnout (Armstrong, 2001). Teachers strive to have a good performance record. Okumba (1998) defines performance as outcomes of work. Thus what people do (their work), how they do it (their behaviour), and what they achieve (results) is all related to work (Okumba 1998). In schools, there are a number of measures put in place to control teachers' performance. Teachers go through the set programmes, though there exist differences in the academic 
performance of schools, some schools perform better than others. What could be the difference between the teacher in schools that perform well and those that do not perform well? Could the teachers be worn-out and are working but in a state of burnout? The study sought to investigate the causes of burnout among secondary school teachers in Bungoma North District.

\section{Objective of The Study}

The objective of this study was to investigate the causes of burnout among secondary school teachers in Bungoma North District.

\section{Methodology}

This study adopted a survey research design. According to Mugenda (2003), Oso (2005) and Kisilu (2006), this method is effective in collecting descriptive data concerning the characteristics of a population. The survey design was used to obtain information on teachers' and principals' perceptions on the causes of burnout. Both qualitative and quantitative data was collected, organized, categorized into themes, coded and analyzed using basic descriptive statistics. Results were presented using percentages, tables, pie charts and graphs.

\section{The Study Area}

This study was conducted in Bungma North District of Bungoma County in Kenya from 2009 to 2010. It has an approximate area of 179.7 sq kilometers, it boarders Trans-nzoia District to the East, Mt. Elgon District to the North, Lugari District to the South and Bungoma East District to the West. The District is densely populated with 792 people per square kilometer as per the 2008 population projection. The age cohorts especially 10 to 14 years are 198, 402 while 15 to 19 years are 155, 711 youths. This is the secondary school going age in the district. Agriculture is the main economic activity (Bureau of Statistics - Bungoma, 2007).

\section{Study Population}

At the time of the study, there were 37 registered secondary schools out of which 9 were provincial and 28 were district schools (Bungoma North District Education Office, 2009). As at the time of study, the district had a total of 544 secondary school teachers and 37 principals. The performance of the schools is competitive especially in national examinations although in some schools results keep fluctuating despite of all efforts put forth by the teachers.

\section{Sampling Procedure \& Sample Size}

Stratified random sampling was used to select schools from which teachers and principals were drawn to ensure proportionate representation of the population in the sample (Oso, 2005). The schools were categorized into strata of provincial boys' schools, mixed schools and girls' schools. Then district boys' schools, girls' schools and mixed schools as illustrated in Table 1.

A sample of 180 (33\%) of the teachers' population (544) was selected. Ten teachers from each sample school filled the questionnaire. (Kombo \& Tromp, 2006). 
INTERNATIONAL JOURNAL OF ACADEMIC RESEARCH IN PROGRESSIVE EDUCATION AND

DEVELOPMENT

Vol. 1, No. 4, 2012, E-ISSN: 2226-6348 @ 2012 HRMARS

Table 1: Study sample (Teachers)

\begin{tabular}{|l|l|l|}
\hline School type & No. of schools & No. of teachers \\
\hline Provincial boys & 2 & 20 \\
\hline Provincial girls & 1 & 10 \\
\hline Provincial mixed & 2 & 20 \\
\hline District boys & 3 & 30 \\
\hline District girls & 3 & 30 \\
\hline District mixed & 7 & 70 \\
\hline Total & $\mathbf{1 8}$ & $\mathbf{1 8 0}$ \\
\hline
\end{tabular}

\section{Instruments For Data Collection}

Data was collected using questionnaire, document analysis, and observation schedule for teachers and interview schedule for the principals. Questionnaire was preferred since it would allow the researcher to get the views, opinions and perceptions of the respondents and also suited the literate population (Kothari, 2004). Teachers' questionnaire was designed to collect data concerning teachers' work related issues and their perceptions on the same. The principals' interview schedule was to provide more clarifications, elaborations and explanations of the teachers' work related issues. The observation schedule was to get information related to the teachers' performance of tasks in relation to professional documents, marking, and their perceptions towards the tasks. (Oso anel onen, 2008).

\section{Instrumentation}

The instruments of the study were developed and the relevance of the instruments was assessed by conducting a pilot study on a sample of twenty teachers from schools that did not participate in the actual study. Questionnaires were administered to the respondents and their responses were verified to check if they were consistent and elicited the expected responses. Ambiguities in the tools were corrected.

\section{Method of Data Analysis}

The collected data from the questionnaire was coded, classified and tabulated. It was then analyzed using descriptive statistics of percentages and frequencies which were worked out manually by the researcher. Data collected through interviews, document analysis and observation schedule were categorized into themes and patterns, coded and analyzed using descriptive statistics to indicate frequencies and percentages.

\section{Results and Discussion}

The purpose of this study was to find out the causes of burnout among secondary school teachers. Factors that were looked at as possible causes were; length of stay in a working station, number of lessons that a teacher taught, how regular school work was taken home, teachers' perception on other assigned responsibility and any other factor that might affect the effectiveness of their performance.

The study revealed that teachers in Bungoma North District were trained professionals and could have chosen teaching as their vocation. Majority had a teaching experience of eleven to fifteen years which put them in a better position to rate their performance in relation to 
teacher burnout. The study further revealed that teachers handled students on a daily basis and were exposed to classroom challenges. Concerning causes of burnout were:

\section{i) Length of Stay in Teaching Station}

It emerged that majority of teachers had been in their stations for three and more years. Facing the same routine and challenges for long was monotonous. Exposure to new work experiences would revitalize the teachers.

\section{ii) Number of Lessons}

The study revealed that majority of the teachers had twenty to twenty four lessons per week. These were within the acceptable range according to the teachers' employer, TSC. However the findings revealed that remedial teaching, holiday and weekend tuition, class discussions and intensive testing policies have added to the teachers' workload making work overwhelming. This causes stress and eventually burnout.

The introduction of Free Primary Education (FPE) and Subsidized Secondary Education by the government has lead to the increase in the number of learners in classes. According to a study conducted by Nyongesa (2007) on factors influencing teachers' performance, a teacher on average will be competent at twenty seven lessons of 40 students per stream, though a teacher will be more competent if lesser lessons were assigned. With the FPE, a teacher handles a class of 50 students on average. With the intensive testing policies and beating deadlines, teachers find it hard to cope. The study revealed that $43.3 \%$ of the respondents carry school-work home. Capel (1987), in his study found out that taking school-work home more often reduces the teacher's time to be refreshed. Lack of refreshment and exercise can lead to burnout. Blonna (2005), also found out that taking work home on a regular basis cause burnout.

Interview with the principals of the sample schools revealed that schools had other extra academic programmes apart from the time- tabled lessons that teachers had. From the interviews, $83.3 \%$ of the principals stated that secondary school teachers were having more than enough workload which can impact on teachers negatively.

\section{iii) Other Responsibilities}

Teachers were happy with other assigned responsibilities such as head of department, head of subject and, house master/mistress. Majority teachers (69.4\%) stated that this leads to an increase in social status, allowances and added value to the curriculum vitae.

\section{iv) Other Factors}

There were other factors which were identified as causes of burnout in teachers. They are presented in table 2 .

Table 2. factors causing burnouts

\begin{tabular}{ll}
\hline & \\
Students' indiscipline & $75.6 \%$ \\
Poor work environment & $75.6 \%$ \\
Lack of teaching resources & $68.9 \%$ \\
Lack of support from administration & $64.4 \%$ \\
\hline
\end{tabular}


Among other factors that were found to cause burnout were as presented in table 2. Kamau (1992) in his study on teacher burnout in Eastern Province of Kenya found out students' indiscipline as a cause of teacher burnout. This finding agrees with Kyricicou (2001), who also found out that student indiscipline and behavioural problems were a major cause of teacher burnout among teachers. With the large classes to handle, discipline and behaviour problems are bound to be a challenge to the teacher. A taskforce on student indiscipline and unrest, established by the Ministry of Education (2002), in its report recommended guidance and counseling after the ban of the use of the cane to promote discipline in schools. Poor working environment was cited by $75.6 \%$ of the respondents. The working environment includes school physical and social environments in terms of the type of buildings, size of the classroom, library facilities, staffrooms, kind of furniture and toilets. The physical environment ought to be conducive and attractive to teachers and other workers in the school. Teachers need enough resources, great support and encouragement for them to perform well. Lack of teaching resources was cited by $68.95 \%$ of the respondents while $64.4 \%$ of them cited lack of support from administration as other causes of burnouts. A high quality environment provides cultural, social and spiritual enhancement of workers (Hofstein et al, 1979).

In education it is important that each individual student gets personalized attention. The large classes and much paper work affected the overall performance of teachers as $59.4 \%$ respondents feared for poor results in their teaching subjects.

\section{Conclusion}

From the study findings, it is evident that teachers are exposed to classrooms full of students, have to play the roles of classroom teachers, examiners, administrators, disciplinarians, counselors and ensure students achieve highly. All these done regularly add up to a large workload making teachers overwhelmed, drained and exhausted. Teaching is a helping profession with a high need of approval and heightened expectations which if not achieved can lead to frustration and burnout.

\section{Recommendations}

Basing on this study findings, it is recommended that teachers' workload should be reduced by employing more teachers. Ways of reducing burnout can be regular transfers, motivation through promotion and giving teachers proper relaxation time.

\section{References}

Armstron, M. (2001): A handbook of human resource management practice. $8^{\text {th }}(\mathrm{ed})$, Kopen. Blonna, R. (2005): Coping with stress in a changing world. $3^{\text {rd }}(\mathrm{Ed})$, Mc Graw-Hill companies: New York,

Capel, S. A. (1987): The incidences of and influences of stress and burnout in secondary Teachers: British Journal of Educational Psychology, 57 (7).

Chance, P. (1981): That burned out, used-up feeling Psychology Today. Prentice Hall, New Delhi.

Karugu, G. (1980): An investigation into job satisfaction among elementary school teachers in Nairobi; PhD thesis. Nairobi. 
Kamau, M. (2003): Factors contributin to Job Satisfaction and Dissatisfaction among secondary school teachers in Githunguri Division, Kiambu District. M.Ed. Thesis, Kenyatta University.

Kisilu, K., \& Tromp, D. (2006): Proposal and Thesis writing: An Introduction, Don Bosco printing press, Makuyu.

Locker, T. (2007): Managing stress, sage publishing company; New Delhi.

Mugenda, M. (2003): Research Methods; Quantitative and Qualitative Approaches. Acts Press, Nairobi

Moully, U. (1978): Education Research, the art and Science of Investigation: Boston Ally \& Bacon.

Ministry of Education. (2002): Report of the Task Force on students' unrest in Secondary schools, Educational and Technical Publishing services, Nairobi.

Nyongesa, S. (2007): Use of Motivation in influencing academic task performance among teachers in top achieving public high schools. M.Ed. thesis, Kenyatta University

Okumbe, J. A. (2007): Educational Management Theory and Practice - Nairobi University Press, Nairobi.

OSO, W. Y., \& One, D. (2008): A general guide to writing Research Proposal and report. A Hand Book on beginning Researchers. $2^{\text {nd }}$ edition, Makerere University, Uganda. 